\title{
A New 'Gender' Definition in International Law: the Convention on Preventing and Combating Violence against Women and Domestic Violence
}

\author{
Francesco AGNELLO*
}

\begin{abstract}
The Convention on Preventing and Combating Violence against Women and Domestic Violence is one of the very first treaties providing for a 'gender' definition and the first ever introducing a definition based on the so-called 'social theory of gender'. The present contribution is devoted to the study of this definition and of its philosophical, political and juridical implications, which are of great relevance for international and national law. It aims at demonstrating the high criticism implied in the choice to include a definition of the term 'gender' in this treaty and in the option to elect a 'social definition'. It seems that defining gender this way and in this context caused many problems from the theoretical perspective, along with concerns of judicial and political nature for states parties, who are prevented from broadly taking part to the Convention, thus generating an important delay in the adoption of the Convention itself and putting in danger the protection of the rights it aims at.
\end{abstract}

Keywords: Gender - Domestic Violence - Istambul Convention.

\section{INTRODUCTION}

On the occasion of its $12 \mathrm{I}^{\text {st }}$ Session (held in Istanbul, on IO-II May 20II), the Committee of Ministers of the Council of Europe ${ }^{\mathrm{I}}$ opened for signature a new treaty, namely, the Convention on preventing and combating violence against women and domestic violence, also called 'Istanbul Convention'. ${ }^{2}$ It had been previously adopted by the Committee of Minister's Deputies on 7 April, 20II, ${ }^{3}$ on the basis of the Draft Convention elaborated by the Ad Hoc Committee on Preventing and Combating Violence Against Women and Domestic Violence (generally called 'CAHVIO', with its French acronyms). ${ }^{4}$ The treaty, open for signature also by the non-member states which have participated in its

PhD in "Human Rights: Evolution, Protection and Limits" at the Università degli Studi di Palermo, Italy; Phd in International Law at the Universitat Jaume I, Castellón de la Plana, Spain; Doctor Europaeus. Contracted Professor at the University of Palermo.The Author thanks the two anonymous reviewers for their suggestions and constructive comments. Email: francesco.agnello@unipa.it.

According to the Art. I5.a of the Statute of the Council of Europe, the Committee of Ministers "shall consider the action required to further the aim of the Council of Europe, including the conclusion of conventions and agreements". Until today, 215 among standard-setting instruments and protocols have been opened for signature.

Convention CETS No. 210. The text of the Convention in its original English and French version is available at http://www.conventions.coe.int/ (accessed 4 September 2014). The opening ceremony has been held at Çırağan Palace in Istanbul on II May 2011.

3 The IV ${ }^{\text {th }}$ meeting held in Strasbourg, 6-7 April 20II.

4 The Ad Hoc Committee on Preventing and Combating Violence against Women and Domestic Violence is an organism settled up by the Council of Europe in order to prepare a convention to prevent and fight domestic violence and other forms of violence against women and to protect and support the victims. It began its work in April 2009. During its $8^{\text {th }}$ meeting (Strasbourg, I3-17 December 2010), it approved the Draft Convention, and during its $9^{\text {th }}$ meeting (Strasbourg, I82I January 20II) the Explanatory Report. For more information regarding CAHVIO, see <http://www.coe.int/t/dghl/standardsetting/violence>,accessed 4 September 2014. 
elaboration and by the European Union, and for accession by other non-member states, was originally ratified only by Turkey (I4 March 20I2), followed - more than three years having passed since the opening for signature of the treaty - only by a quite small minority of states. The tenth state ratified the Convention only in April 2014 which therefore entered into force on I August 2014, according to Article 75, Paragraph 3 of the Convention itself.5 This Convention commendably has the aim to

a. protect women against all forms of violence, and prevent, prosecute and eliminate violence against women and domestic violence; $b$. contribute to the elimination of all forms of discrimination against women and promote substantive equality between women and men, including by empowering women; $\mathrm{c}$. design a comprehensive framework, policies and measures for the protection of and assistance to all victims of violence against women and domestic violence; $d$. promote international co-operation with a view to eliminating violence against women and domestic violence; e. provide support and assistance to organizations and law-enforcement agencies to effectively co-operate in order to adopt an integrated approach to eliminating violence against women and domestic violence. ${ }^{6}$

From this perspective, the treaty recognizes violence against women as a violation of human rights ${ }^{7}$ and in some cases identifies it as a crime, binding parties to introduce a set of ground-breaking criminal offences in their national systems - such as stalking, ${ }^{8}$ forced marriage, ${ }^{9}$ female genital mutilation, ${ }^{\text {IO }}$ forced abortion and forced sterilization ${ }^{\text {II }}-$ alongside more 'classical' crimes affecting women's rights. ${ }^{\mathrm{I2}}$ Moreover, it calls for an effective coordination among all relevant agencies, institutions and organizations ${ }^{13}$ and for an international cooperation among states, ${ }^{14}$ in order to act in a coordinated way in fighting violence against women and domestic violence.

The treaty is structured in I2 chapters thoroughly dealing with the various aspects of the phenomena of domestic violence and violence against women. Its provisions affect prevention aspects

5 The Convention has been signed by the following Member states: Austria, Finland, France, Germany, Greece, Iceland, Luxemburg, Montenegro, Portugal, Slovakia, Spain, Sweden, and Turkey. Subsequently, other Member states signed it: Norway (7 July 20II), the Former Yugoslav Republic of Macedonia (8 July 20II), Slovenia (8 September 20II), Belgium (II September 20II), Ukraine (7 November 20II), Albania (19 December 20II), Serbia (4 April 20I2), Malta (2I May 20I2), United Kingdom (8 June 2012), the Netherlands (I4 September 20I2), Monaco (20 September 20I2), Italy (27 September 20I2) Poland (18 December 20I2), Croatia (22 January 2013), Andorra (22 February 20I3), Bosnia and Herzegovina (8 March 2013) Lithuania (7 June 20I3),Switzerland (II September 20I3) Denmark (II October 20I3), Hungary (I4 March 20I4), San Marino (30 April 2014), Georgia (19 June 2014) and Romania (27 June 2014). It has been ratified by Albania (4 February 2013), Portugal (5 February 2013), Montenegro (22 April 2013), Italy (10 September 2013),Bosnia and Herzegovina (7 November 2013), Austria (I4 November 2013), Serbia (2I November 2013), Spain (I0 April 2014), Andorra (22 April 2014), Montenegro (22 April 20I4), Denmark (23 April 20I4), Sweden (I July 20I4), France (4 July 20I4), Malta (29 July 20I4) and Monaco (7 October 20I4).

6 See $\operatorname{Art.} I(a)$.

7 See Art. 3 .

8 See Art. 34.

9 See Art. 37.

Io See Art. 38 .

II See Art. 39.

I2 Among these, the Convention lists 'Psychological violence' (Art. 33), 'Physical violence' (Art. 35), 'Sexual violence, including rape' (Art. 36), 'Sexual harassment' (Art. 40). The Convention extends the obligations flowing from Art. 36 also "to acts committed against former or current spouses or partners as recognized by internal law", while admitting that the conducts enumerated in Art. 40 can be "subject to criminal or other legal sanction". See the whole Chapter V, devoted to "Substantive Law", Arts. 29 to 48.

I3 See Chapter II, Arts. $7 \mathrm{ff}$.

${ }^{14}$ See Chapter VIII, Arts. $62 \mathrm{ff}$. 
in depth, by means of awareness-raising, ${ }^{15}$ education, ${ }^{16}$ training of professionals, ${ }^{17}$ involvement of the private sector and the media ${ }^{\mathrm{I} 8}$ and treatment programmes aimed at preventing perpetrators of violence against women from re-offending. ${ }^{19}$

Chapter IV of the Convention is fully devoted to another central issue: protection and support of the victims. It contains - among others - detailed measures on specialist support services, ${ }^{20}$ assistance in individual and collective complaints, ${ }^{21}$ the setting-up of concrete appropriate facilities such as shelters and telephone helplines, ${ }^{22}$ and special support for victim of sexual violence and for child witnesses. ${ }^{23}$

The treaty contains also detailed provisions on investigation, prosecution, procedural law and protective measures ${ }^{24}$ - with special attention to timely intervention ${ }^{25}$ and prevention, ${ }^{26}$ also by means of emergency barring, restraining or protection orders,$-{ }^{27}$ as well as dispositions concerning international cooperation in civil and criminal matters. ${ }^{28}$ Particular attention is dedicated to special categories of victims belonging to particularly vulnerable groups, Chapter VII being devoted to "Migration and Asylum".

Of the utmost importance is also the institution of the "Group of expert on action against violence against women and domestic violence" (named 'GREVIO' by the Convention itself). ${ }^{29}$ According to Chapter IX of the treaty, GREVIO shall monitor the implementation of the Convention by the Parties. In particular it will periodically receive reports submitted by the Parties themselves and based on questionnaires prepared by the Group of experts. ${ }^{30}$ It will receive also information on the implementation of the Convention, from non-governmental organizations and civil society, as well as from national institutions for the protection of human rights ${ }^{31}$. It will also take in due consideration the existing information available from other regional and international instruments and bodies acting in areas falling within the scope of the Istanbul Convention..$^{22}$

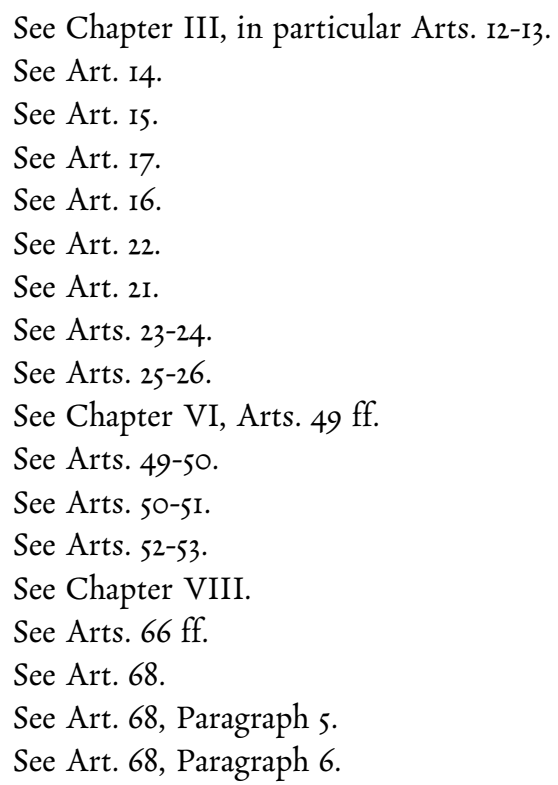


Among the powers of the Group of expert will be also the organization of country visits, whenever the information gained were insufficient ${ }^{33}$ or in case of problems requiring immediate attention to prevent or limit the scale or number of serious violations. ${ }^{34}$

GREVIO will adopt reports, conclusions and recommendations, 35 as well as general recommendations. ${ }^{36}$ According to Article 70, also National parliaments and the Parliamentary Assembly of the Council of Europe will be involved in the monitoring of the measures adopted by states for the implementation of the Convention. ${ }^{37}$

However, the provisions referred above are not the unique point of interest of this Convention, nor - perhaps - the most innovative. The decision, among others, to include a 'gender' definition from the very beginning of the drafting process, and then to insist vehemently on ituntil its final version, generated a great debate. The present contribution is devoted to the study of this 'gender' definition and of its philosophical, political and juridical implications, which are of great relevance for international and national law.

\section{A 'GENDER' DEFINITION}

The previously mentioned relevance is due, first of all, to the fact that the Istanbul Convention is one of the very first treaties providing for a 'gender' definition, and the first ever standard-setting instrument adopting a 'gender' definition based on the so-called 'social theory of gender'.$^{8}$

Article 3 of the Convention, in fact, explicitly defines 'gender' as "the socially constructed roles, behaviours, activities and attributes that a given society considers appropriate for women and men" ${ }^{39}$

Adopting such definition implies highly sensitive theoretical, philosophical and anthropological assumptions and - of course - all of their political and juridical consequences, which are not always clearly understandable at first sight, even for an expert of human rights who is not specialized in gender issues. Indeed, the introduction of a new definition for a term, or the term itself, in the public debate or in a juridical text is often the first step of a larger and deeper juridical struggle, especially in both human rights and bioethics fields. The history of these subject matters is characterized by the success or failure of the attempt to define some given critical concept in a given way or to introduce new notions by creating and introducing new terms in the scientific debate, trying - this way - to orient the scientific debate itself towards a specific direction or to obtain a given juridical effect..$^{40}$

\footnotetext{
33 See Art. 68, Paragraph 9.

See Art. 68, Paragraphs 13-I4.

See Art. 68, Paragraph II-I2.

See Art. 69.

37 See Art. 70.

38 See below, the section "The Lack of International Consent on Such a Definition".

39 See Art. 3(c).
}

${ }^{40}$ It is possible, just to quote some example, to refer to the debate on 'death' definition as 'cerebral death' or 'cardiac death' and to all the consequences of great relevance descending from the adoption of the former or the latter definition, in very relevant and highly sensitive matters, like organ donations. Similarly the definition of 'euthanasia' and 'therapeutic obstinacy' and the outlining of the border between these concepts have relevant and well known consequences. It could be of some utility to recall also the debate on the introduction of the term 'pre-embryo' and its distinction in respect of the 
New definitions, particularly in these fields, quite always assume new ground-breaking philosophical or anthropological views, to which their authors try to conform the juridical system.

Opting for a socially-based 'gender' definition - it is well known - means, first of all and at least, to affirm not just a distinction between 'gender' and 'sex', but rather a substantial dichotomy between these concepts, thus denying the fact that these are even respectively linked. On the contrary, it means to maintain a structural and ontological differentiation between these two categories: while sex is given in nature, gender is just a social, cultural and education product, having absolutely nothing to do with the former concept. ${ }^{4 r}$

According to the theories grounded on a socially-based definition, 'gender' is totally split and independent from biology, thus making it absolutely irrelevant for a person to be born male or female and considering any difference between these categories being due solely to culture. Every person, at the moment of his/her birth is a 'neuter' human being and it will be society, education and selfdetermination that will determine his/her gender. ${ }^{42}$

One of the intents of the social theories of gender, this way, is the deconstruction of any identity that contemplates a reference to maleness or femaleness, thus aiming at establishing a society where sexual differences are regarded as absolutely immaterial (and inexistent), anyone being free to build up his/her personal gender identity.43 By doing so, these theories deny any difference of any nature between men and women, affirming that such difference is only of a social nature.

This, in turns, opens the door to another two-faced relevant consequence, coming directly from the acceptance of such a definition: if gender is conceived as a social construct, then a social evolution of this construct is legitimate, both from a general, collective perspective and from a personal, subjective one. From the former point of view, splitting 'sex' and 'gender' and redefining the latter as a social construct means to accept theoretical constructions - such as 'multigender', 'postgender', 'transgender' and 'queer' theories-, based on the deconstruction of the concepts of gender and sex themselves. ${ }^{44}$ These theories aim explicitly, in a first instance, at affirming the existence of more than

'embryo', that has relevant consequences in the debate on pre-natal life, abortion, stem cells, etc. Among many, see M. A. Peeters, 'The Gender Ideology and the Global Language', in Ángela Aparisi Miralles (ed), Persona y genero (AranzadiThomson Reuters-Universidad de Navarra, Instituto de ciencias para la Familia, Pamplona, 20II), III-I24.

${ }_{41}$ Among others, see R. Stoller, Sex and Gender, The Development of Masculinity and Femininity (Science House, New York City, 1968) which affirms, at 29: "The two realms (sex and gender) are not inevitably bound in anything like a one-toone relationship, but may go into quite independent ways". Similarly, J. Butler, Gender Trouble: Feminism and the Subversion of Identity (Routledge, New York City, 1990, ed. 2007), at 8 affirms "gender is neither the causal result of sex nor as seemingly fixed as sex", and at 9 "If gender is the cultural meanings that the sexed body assumes, then a gender cannot be said to follow from a sex in any one way. Taken to its logical limit, the sex/gender distinction suggests a radical discontinuity between sexed bodies and culturally constructed genders." For an overview on the development and the content of gender theories see L. Palazzani, Sex/gender: gli equivoci dell'uguaglianza (Giappichelli, Torino, 2oII); Á. Aparisi Miralles, 'Ideología de genero: de la naturaleza a la cultura', 6I Persona y Derecho (2009)I69-193; L. Palazzani, 'Teorizzazione del "gender" tra filosofia e diritto', in Aparisi Miralles supra n 17 at 95; and L. Scaraffia, 'Riflessioni sul contesto storico culturale in cui nasce la teoria del gender', ibid.,39.

${ }_{42}$ S. De Beauvoir, Le Deuxième Sexe (Gallimardo, Paris, 1949) affirms, at 285-286. "On ne naît pas femme: on le deviant"; similarly, K. Millet, Sexual Politics, (Doubleday, New York City, 1970) at 54 states: "there is no differentiation between the sexes at birth. Psychosexual personality is therefore postnatal and learned".

${ }_{43}$ It could be of some utility to underline that 'gender identity' is conceptually different from 'sexual orientation' and these concept are not to be confused.

${ }_{44}$ Butler, supra n. 4I, at 9 reads: "When the constructed status of gender is theorized as radically independent of sex, 
two genders ${ }^{45}$ and, more recently, at creating a neutered kind of human being, a "universal sexual legal subject" ${ }^{46}$ whose gender is indefinite and indefinable, unstable, and above all juridically immaterial. ${ }^{47}$

From the subjective point of view, in denying any objectivity to the concept of gender, the social theories propose a 'nomad' gender subjectivity, i.e. a subjectivity that, being indefinable and not related with objective elements, is complex, multiplex and mutable. This gender malleability —ça va sans dire - is not dependent nor related with any sex modification (being transgenderism and transsexualism two conceptually different phenomena) and depends only on the contingent will or, more simply, feelings of the single individual. Being conscious that gender is in no way related with biology, but it rather is artificially 'imposed' by education and society, each individual can claim for his/her right to exercise his/her freedom, also in this field. So, as a consequence of the social theory of gender, a single person can chose his/her gender every time he/she wants, just opting for one or the other (at least until society and law don't admit the existence of a unique gender).

A radically different perspective is assumed instead by the so called biological' or 'natural' theories of gender, according to which, gender is intimately and bi-univocally linked to sex. As a consequence, according to these theories, there are only two genders (masculine and feminine), corresponding respectively to male and female sex.

Given the tight relation recognized between these concepts, the 'biological' theory conceives gender as given in nature, together with sex. Yet these theories note that dimorphism has a basis in gametogenesis (i.e. in the formation of sexual gametes, male and female) and think of it as an absolute concept. They ground their roots in genetics and in the objective evident distinction between each and every cell of male (each containing XY chromosomes) and female individuals (all characterized by $\mathrm{XX}$ chromosomes). Of course there are also radical biological theories according to which a given sex and a given gender mean also given social roles, duties and behaviours, consequently denying every social, cultural and educational influence in creating them. These theories, by radicalizing what is contingent, allow and justify stereotypes and prejudices created by cultures that 'contribute to make violence against women acceptable'. For this reason they have to be strongly rejected.

gender itself becomes a free-floating artifice, with the consequence that man and masculine might just as easily signify a female body as a male one, and woman and feminine a male body as easily as a female one" and "perhaps this construct called 'sex' is as culturally constructed as gender'. M. Grigolo, 'Sexualities and the ECHR: Introducing the Universal Sexual Legal Subject', I4,5 European Jourmal of International Law (2003) 1023-I044, at I025 affirms: "It is precisely the need to overcome these conceptual limits that has caused a number of feminist and so-called 'queer' theorists to seek to revise essentialism within a constructionist perspective. At the purely theoretical level, it has become evident that, in order to eliminate the dichotomy, it is necessary to contest the poles and problematize the binary construction of gender and sexuality. Instead of taking categories such as 'sex' or 'homosexual' as fixed and given, post-modern 'queer' theorists have stressed their artificiality and their role in reproducing a system of domination. Butler has undermined the very naturalness of the category of 'sex'."

45 Some authors also affirmed the existence of more than two sexes. Among others see A. F. Sterling, 'The Five Sexes: Why Male and Female are not Enough', The Science (1993) 20-24.

${ }_{46}$ Grigolo supra n.44 at 1039. See also D. J. Haraway, Simias, Cyborgs and Women. The Reinvention of Nature (Routledge, New York, 199I).

47 See ibid. For example, M. Warner, The Trouble with Normal. Sex, Politics, and the Ethics of Queer Life (University Press, Harvard, 2000) affirms at 39 "even an expanded catalogue of identities can remain blind to the ways people suffer, often indiscriminately, from gender norms, object orientation norms, norms of sexual practice, and norms of subjective identification". 
The most equilibrate among gender theories - according to the opinion of the author of this contribution - seems to be the 'personalistic' one. This conception recognizes the distinction between 'sex' and 'gender', the first notion relating to the biological dimension, the second taking into account the historical and cultural aspects, and affirms the necessity not to muddle these two perspectives and plans of analysis. The personalistic gender theory, does not deny that culture, society and education play a great role in forming and defining the human person, also on gender aspects, but affirms at the same time that the formation of a gender identity is a socio-psychological process that has as a basis in the ontological reality attached to a given male or female sex. This way, the personalistic theory on gender describes and brings back to unity the complex reality of the human being, by affirming that the human person is made of will, freedom and reason, together with body: culture, society and personal choices are relevant of course, but they cannot put aside and annihilate body and corporeity. According to this theory a 'universal sexual legal subject', an individual juridical subject whose sex is absolutely immaterial for law, appears like an abstraction which denies reality.

The personalistic theory of gender, indeed, tributes to gender and sex an ontological and constitutive relevance in formulating the concept of 'person' - from the philosophical, anthropological and juridical point of view - without prejudice to the absolute equality in rights and dignity between male and female human beings. It recognizes that in real life, the function and roles attributed to men and women are strongly influenced by stereotypes and prejudices created by culture, education and society; however, this theory of gender affirms that the best way to eradicate prejudice and stereotypes is to fight against them, affirming the ontological equality in dignity and rights between men and women by using all juridical, cultural and social means, and not to split gender from sex or to affirm a unique fluid gender personality. ${ }^{48}$ In the same way, it deals with any human rights issue related with sexuality, homosexuality, transsexuality, etc. from a perspective that assumes any sexual preference or orientation as logically different and subsequent to a given sex and gender.

Anyway, this contribution does not intend to discuss on gender theories and definitions from a theoretical point of view, since these issues are broadly and deeply studied already. It will instead concentrate on the 'gender' definition concretely adopted by the 'Istanbul Convention', aiming at demonstrating the futility, dangerousness and high criticism of the choice to include a definition of the term 'gender' in this treaty and, furthermore, of the option to elect a 'social definition' of this concept. ${ }^{49}$ The author of this contribution, in fact, strongly believes that defining gender in this context, being an unnecessary and maybe also dangerous choice just for those human rights that the Convention aims at declaring and protecting, causes many problems from the theoretical perspective, along with concerns of judicial and political nature for states parties. Regrettably, this puts the large participation of states in the Convention (and the related protection of women's rights which it aims

${ }_{48}$ See, among others, Palazzani, Sex/Gender..., supra n. 4I, particularly at 99 ff.; M. Elósegui Itxaso, 'Tres diversos modelos filosóficos sobre la relación entre sexo y género', in Persona y genero, supra n. 40, at 53-75; J. M. Burgos, Dos formas de afrontar la identidad sexual: personalismo e ideología de género, in ibid., at 405-42I.

49 For a general comment on the Istanbul Convention see, among others, A. Di Stefano, 'Violenza contro le donne e violenza domestica nella nuova Convenzione del Consiglio d'Europa', 6, I Diritti Umani E Diritto Internazionale (2012) I69I75. 
at) in danger and could be an alarming source of serious and unpredictable international responsibility for states parties, in the future.

\section{THE UNNECESSARINESS OF A 'GENDER' DEFINITION FOR THE PURPOSE OF THE CONVENTION}

Firstly, as mentioned above, a definition of 'gender' is absolutely useless for the purpose of this Convention: in a women rights' perspective, such a definition — and the theories behind it - adds nothing to the protection of women as conceived in the articles of the treaty.

A first evidence of this uselessness can be deducted by the analysis of Article 3 itself which, at its letter (a), defines "violence against women" as "a violation of human rights and a form of discrimination against women and shall mean all acts of gender-based violence that result in, or are likely to result in, physical, sexual, psychological or economic harm or suffering to women, including threats of such acts, coercion or arbitrary deprivation of liberty, whether occurring in public or in private life". No place for 'gender' is granted in the concept of 'violence against women' itself.

The uselessness of such a definition is even more evident, when observing that the letter (b) of the same Article 3, defines "gender-based violence against women" as "violence that is directed against a woman because she is a woman or that affects women disproportionately", giving no relevance also in this case - to 'gender' as intended by letter (c) of the same Article.

Furthermore, the definition of 'woman' is not included in Article 3 of the Convention, which merely states that "women' includes girls under the age of 18 "..$^{\circ}$ Therefore, this term has to be interpreted referring to the ordinary meaning it should have, as confirmed also by Paragraph 43 of the Explanatory Report of the Convention:-5in commenting Article 3 (c), it explicitly states that "The term 'gender' under this definition is not intended as a replacement for the terms 'women' and 'men' used in the Convention".

Starting from these data, it follows that, for the purpose of this Convention, the terms 'violence against women', 'gender-based violence against women' and 'women' are to be intended from a 'sexbased' perspective. In fact, it's easy to see how the very structure of this terminology leaves no place for using the gender definition contained in the same Article: defining 'gender' in one way or in another, or even not defining it at all, has no effect at all on strengthening the protection offered by the Convention to women from 'violence against women' and 'gender-based violence'.

Such conclusion is upheld by the study of the Explanatory Report of the Convention which, at the same time, highlights another aspect of this uselessness. In explaining the nature and the scope of the definition contained in Article 3 (c), Paragraph 43 of the above mentioned Report links the introduction of such a definition with the purpose to eradicate customs, traditions, prejudices and

\footnotetext{
50 See Art. 3(f).

5I The text of the Explanatory Report in its original English and French version is available at http://www.conventions.coe.int/ (accessed 4 September 20I4).
} 
other practices which are based on the idea of the inferiority of women or on stereotyped gender roles, that "contribute to make violence against women acceptable"..$^{2}$

However, in its attempt to link the 'gender' definition concretely contained in Article 3 of the Convention with that praiseworthy aim, this Paragraph lacks in providing any argument in support.

In particular, it omits any reference to the option made by the CAHVIO in electing a 'social' gender definition rather than choosing a definition that, while admitting the relevance of education and society, recognizes relevance also to sex. As briefly recalled in the former section, this noble struggle of fighting against prejudice and stereotypes can be equally conducted starting from a definition which admits the relevance of the biological data. It is possible to fight for a real equality between men and women also without splitting sex by gender or affirming the exclusive relevance of society, culture and education in determining the latter. In the view of the author of this contribution, the best way to achieve the above mentioned noble goal would be the adoption of a so called 'personalistic' perspective, i.e. a perspective that even though admitting the relevance of society and culture in assigning roles and duties to men and women, it doesn't affirm the absolute irrelevance of the sex; although affirming the absolute equality between men and women in law and dignity, such perspective recognizes the relevance of the biologically given differences and the necessity to affirm their juridical significance.

Moreover, it is possible to easily argue that, if the purpose is to fight against such heinous prejudices flowing from the idea of the inferiority of women and stereotyped gender roles, the best -if not the only - way to achieve it, should be to act by promoting specific objectives in education and culture, and not by introducing new definitions which imply complex and deep ideological options, having large consequences on the social structure (and related larger 'costs' to be paid from a social and juridical point of view), unnecessary to the achievement of the aim itself.53

Indeed, CAHVIO correctly outlined these means in Articles I2 and I4 of the Draft Convention, ${ }^{54}$ the first one recalled by the above mentioned Paragraph 43 of the Explanatory report itself. According to Article I2, Paragraph I

Parties shall take the necessary measures to promote changes in the social and cultural patterns of behaviour of women and men with a view to eradicating prejudices, customs, traditions and all other practices which are based on the idea of the inferiority of women or on stereotyped roles for women and men.

In a similar way, Article I4, Paragraph I, provides:

Parties shall take, where appropriate, the necessary steps to include teaching material on issues such as equality between women and men, non-stereotyped gender roles, mutual respect, non-violent conflict resolution in interpersonal relationships, gender-based violence against women and the right to personal integrity, adapted to the evolving capacity of learners, in formal curricula and at all levels of education.

While, according to Paragraph 2 of the same Article,

52 See Paragraph 43 of the Explanatory Report.

53 Art. 5 of the Convention on the Elimination of All Forms of Discrimination against Women (hereinafter the CEDAW), adopted I8 December 1979 by the UN General Assembly, entered into force 3 September 198I(I249 UNTS I3) for example, pursues the same commendable goal without any reference to a 'gender' definition.

${ }_{54}$ These articles have been approved, without any modification, as Arts. I2 and 14 of the Convention. 
Parties shall take the necessary steps to promote the principles referred to in paragraph $\mathrm{I}$ in informal educational facilities, as well as in sports, cultural and leisure facilities and the media.

The way shown by these dispositions appears to be the most useful - even if it would have been desirable that stronger and more stringent provisions were outlined in this field - in order to pursue, in a very concrete way, the elimination of such heinous prejudices. Similarly to what has been observed at the opening of this section, the gender definition contained in Article 3 and the theories by which it stems add absolutely nothing to women protection, also from this perspective. On the contrary, Articles I2 and I4 seem to assume a classical, 'sex'-based perspective, by speaking of 'men and women' and not of 'gender'. This makes Paragraph 43 of the Explanatory Report and its explanation on the utility of 'gender' definition even more inconsistent: given the way Articles I2 and I4 are structured - seeming to rest on the biological or personalistic theories of 'gender', by its reference to 'women and men' and containing no reference to the social theory- if Article 3 (c) has been introduced to pursue the goal affirmed by Paragraph 43, the above referred definition is absolutely useless and even detrimental to the goal itself, in the economy of the treaty.

The analysis of the remaining articles of the Convention which take the 'gender's5 into consideration seems to lead to a similar conclusion as well. In some of these dispositions, however, 'gender' definition is not simply 'immaterial', as it is in the articles examined above. On the contrary, it adds unclear and sometimes unexpected meanings to the provisions contained in them, by indirectly recalling the 'social' gender theories, when using the term 'gender' as defined in Article 3 and by introducing - this way- obligations and duties about which states parties could be not conscious. ${ }^{56}$

Furthermore, the futility of a gender definition and of the related theories in a more effective defence of women's rights and in the fight against gender based violence and discrimination is demonstrated by a simple study of the text of the most important international legal instruments adopted on such matters. Everyone, in fact, can easily notice that no 'gender' definition is contained in any of the principal international treaties and declarations concerning women's rights or human rights: none of the many international instruments recalled in the Preamble of the Istanbul Convention, ${ }^{57}$ nor those recalled in the "Compilation of international legal instruments relevant to the

55 In particular, the term 'gender', as defined in Art. 3(c) of the Convention, is used in Arts. 6, I4, I8, Paragraph 3, 49, Paragraph 2, 60, and 66 of the Convention itself.

56 See below, the section "The Danger of Unpredicted and Serious International Responsibility for States Parties".

57 They are the Convention for the Protection of Human Rights and Fundamental Freedoms (adopted 4 November 1950, entered into force 3 September 1953), 213 UNTS 22I, ETS No. 5, 1950, and its Protocols, the European Social Charter Freedoms (adopted I8 October 196I, entered into force 26 February 1965), 529 UNTS 89, ETS No. 35, 196I, revised in ETS No. 163, 1996, the Council of Europe Convention on Action against Trafficking in Human Beings (adopted 16 May 2005), ETS No. 197, 2005 and the Council of Europe Convention on the Protection of Children against Sexual Exploitation and Sexual Abuse (ETS No. 20I, 2007), the recommendations of the Committee of Ministers to member states of the Council of Europe Rec(2002)5 on the Protection of Women Against Violence, Rec(2007)17 on Gender Equality Standards and Mechanisms, $\operatorname{Rec}(2010)$ Io on the Role of Women and Men in Conflict Prevention and Resolution and in Peace Building, the International Covenant on Civil and Political Rights (adopted 16 December 1966, entered into force 23 March 1976), 999 UNTS 17, the International Covenant on Economic, Social and Cultural Rights (adopted 16 December 1966, entered into force 3 January 1976), 993 UNTS 3, the United Nations Convention on the Elimination of All Forms of Discrimination Against Women ('CEDAW', adopted I8 December 1979, entered into force 3 September 198I), I249 UNTS I3, and its 
Ad Hoc Committee on preventing and combating violence against women and domestic violence" ${ }^{88}$ contain a 'gender' definition. ${ }^{59}$ This is true also in respect with the most recent ones among them.

It is noteworthy that these international instruments - some of them being at the cornerstone of women protection - contain and refer to a great number of definitions, but none of them includes a definition of 'gender', even if this term is constantly and repeatedly used, in some of these texts.

Looking over the documents listed by the "Compilation of international legal instruments relevant to the Ad Hoc Committee on preventing and combating violence against women and domestic violence" referred to above, it is possible to read a great variety of definitions of heterogeneous terms like 'women', 'violence against women', 'discrimination against women', 'principle of equal treatment', 'direct discrimination', 'indirect discrimination', 'trafficking in human beings', 'child', 'victim', 'repeat victimization', 'secondary victimization', 'sexual exploitation and sexual abuse of children', 'harassment', 'sexual harassment', 'armful practices', 'family ties', etc., but not a definition of 'gender'.

The analysis of both the American and African counterparts of the Istanbul Convention, respectively the Inter-American Convention on the Prevention, Punishment and Eradication of Violence against Women (also known as "Convention of Belem do Para") ${ }^{60}$ and the Protocol to the African Charter of Human and Peoples' Rights on the Rights of Women in Africa ${ }^{6}$ also leads to the same conclusion.

First of all, none among these regional instruments contains any definition of the term 'gender', even if both of them contain provisions devoted to define the core terms used in the respective text. ${ }^{62}$ Secondly, both the above mentioned regional texts contain dispositions clearly aimed at eradicating prejudice and stereotypes, as well as other practices which are based on the idea of the inferiority of

Optional Protocol (adopted Io December 1999, entered into force 20 December 2000), 2I3I UNTS 83, as well as General Recommendation No. I9 of the CEDAW Committee on violence against women, the United Nations Convention on the Rights of the Child (adopted 20 November 1989, entered into force 2 September 1990), 1577 UNTS 3, and its Optional Protocols (both adopted 25 May 2000, entered into force I8 January 2002), and the United Nations Convention on the Rights of Persons with Disabilities (adopted I3 December 2006, entered into force 3 May 2008) 2515 UNTS 3, the Geneva Convention (IV) relative to the Protection of Civilian Persons in Time of War (adopted I2 August 1949, entered into force 2I October 1950), 75 UNTS 287 and the Additional Protocols I and II (both adopted 8 June 1977, entered into force 7 December 1978), respectively II25 UNTS 3 and II25 UNTS 609. Actually, a definition of 'gender' is contained in the Rome Statute of the International Criminal Court (adopted I7 July 1998, entered into force I July 2002) 2187 UNTS 90, cited in the Preamble of the Draft Convention. On that definition (radically different in nature from the one proposed in the Draft convention approved by the Council of Europe) and on the relevance of this reference we will say more in the next section.

58 This document is electronically available at web page <http://www.coe.int/t/dghl/standardsetting/violence/compilation_en.pdf> (accessed 4 September 20I4).

59 The unique exception is - as noted supra, in n. 57 - the definition of 'gender' contained in the Rome Statute of the International Criminal Court, a treaty cited in the Preamble of the Draft Convention. On this definition, radically different in nature from the one proposed in the Draft Convention, see below, the section "The Lack of International Consent on Such a Definition".

60 Adopted 6 September 1994, entered into force 3 May 1995; text available at <http://www.oas.org/juridico/english/treaties/a-6r.html>, accessed 4 September 2014.

6r Adopted 7 November 2003, entered into force 25 November 2005; text available at <http://www.achpr.org/instruments/women-protocol/>, accessed 4 September 2014.

${ }_{62}$ See Arts. I and 2 of the Inter-American Convention on the Prevention, Punishment and Eradication of Violence against Women and Art. I of the Protocol to the African Charter of Human and Peoples' Rights on the Rights of Women in Africa. 
women or on stereotyped gender roles, that contribute to make violence against women acceptable. ${ }^{63}$ Nonetheless, also in these cases, this aim is pursued by promoting specific objectives in education and culture, in order to affirm the ontological equality in dignity and rights between men and women, while the said articles make no reference to social theories of gender. On the contrary, these dispositions, while pursuing the mentioned praiseworthy aim, make express reference to the concept of 'sexes' or 'men and women', this way making even clearer that no reference (even an implicit one) on the social theories of gender finds place in these regional instruments: ${ }^{64}$ also for the purpose of this international instruments, the terms 'violence against women' and 'women' and all related issues are to be intended from a 'sex-based' perspective.

These facts, together with the lack of relevance of this definition in the Convention in question show once again that women rights can be - and have always been- protected without recurring to social gender theories.

In fact, the lack of such a definition in these standard-setting documents demonstrates how the drafters of the leading international instruments proclaiming and defending women's rights, of international legal texts explicitly and directly centred on gender equality (such as the Recommendation of the Committee of Ministers of the Council of Europe to Member States on Gender Equality Standards and Mechanisms) ${ }^{65}$ and of the most relevant human rights treaties dealing with women rights, as well as the other two relevant regional instruments adopted in the framework respectively of the American and African systems for human rights protection, didn't use the term 'gender' or rather used it according to its ordinary meaning, i.e. - as it will be shown in the next section — as a synonym for 'women' and 'sex'. ${ }^{66}$

\section{THE LACK OF INTERNATIONAL CONSENT ON SUCH A DEFINITION.}

The term 'gender' began to be used in a relevant way in international documents only during the 90s. ${ }^{67}$ However, at the beginning it was used and understood absolutely just like a synonymous of 'women', 'sex' or similar terms. ${ }^{6}$

${ }_{63}$ See Arts. 6 b, 7 e and $8 \mathrm{~b}$ of the Inter-American Convention on the Prevention, Punishment and Eradication of Violence against Women and Arts. 2 Paragraph 2, 4 Paragraph $2 \mathrm{~d}$ and 12 Paragraph I of the Protocol to the African Charter of Human and Peoples' Rights on the Rights of Women in Africa.

${ }^{64}$ As regards the Inter-American Convention on the Prevention, Punishment and Eradication of Violence against Women, Arts. 6(b) and 7(e) refer to 'women', while Art. 8(b) refers twice to 'men and women' and once to 'sexes'. As regards the Protocol to the African Charter of Human and Peoples' Rights on the Rights of Women in Africa, Art. 2 Paragraph 2, makes references to 'sexes' and to 'women and men' while Arts. 4 Paragraph 2(d) and I2 Paragraph I refers to 'women'.

${ }_{65}$ Document n. CM/Rec(2007)r7, adopted by the Committee of Ministers on 2I November 2007, at the Iorith meeting of the Ministers' Deputies, available at <https://wcd.coe.int/ViewDoc.jsp?id=I2I5219\&Site=CM> (accessed 4 September 2014).

66 See J. Adolphe, 'The Meaning of "Gender" Within the United Nations System', in Persona y genero,supra n. I7, pp. I27-I52, at 127 .

${ }_{67}$ On the evolution of the praxis to recur to the term 'gender' in international documents and its relevant consequences see Peeters, supra n. 40 and Adolphe supra n. 66.

68. Ibid.; see also H. Charlesworth, 'Not Waving but Drowning: Gender Mainstreaming and Human Rights in the United Nations', I8 Harvard Human Rights Journal (2005) (also available at <http://regnet.anu.edu.au/sites/default/files/files/Charlesworth_2005.pdf>, accessed 4 September 20I4), I-I8, at I4 ff. 
The first clear and strong attempt to introduce a massive and social-based use of the term took place during the Fourth World Conference on Women, held in Beijing in 1995, whose final document, the Beijing Declaration and Platform of Action, contains the word 'gender' 233 times. In fact, redefining gender as a social construct was a focus of the World Conferences on Women. Nevertheless, when states became aware of the attempt to introduce new concepts and new ideologies, covered behind the introduction of this new term, and of the broad and vague language used, they sought for the opening of a debate on these issues. This discussion brought to the adoption of Annex IV to the Report of the Fourth World Conference on Women, where states specified that "the word 'gender' as used in the Platform for Action was intended to be interpreted and understood as it was in ordinary, generally accepted usage", i.e. as a synonym for 'women' and 'sex'. ${ }^{69}$

In the same manner, when faced with the introduction of the term 'gender' in the Rome Statute that established the International Criminal Court, states strongly claimed for a definition of the term to be included in the Statute itself. This brought to the first and still nowadays only - at least until the 'Istanbul Convention' entered into force- binding definition of 'gender' in International Law.

Unsurprisingly, at that time states opted for a very equilibrated definition, according to which "the term 'gender' refers to the two sexes, male and female, within the context of society. The term 'gender' does not indicate any meaning different from the above" ${ }^{70} \mathrm{~A}$ definition conceived this way, while recognizing the social dimension of "gender', strongly reconnects gender to sex, explicitly affirming at the same time the existence of "two sexes, male and female".

States kept manifesting their consent to such a solution, by adopting the definition contained in the Rome Statute or by taking the Beijing approach, when they needed to define gender. This way, the Report of the United Nations Conference on Human Settlements, held in Istanbul in 1996, expressly and literally recalls the Beijing statement on 'gender', ${ }^{71}$ while during the 200 World Conference against Racism (hereinafter the 'WCAR'), also known as 'Durban I', states adopted the Rome Statute definition, by stating: "For the purpose of this Declaration and Programme of Action, it was understood that the term 'gender' refers to the two sexes, male and female, within the context of society. The term 'gender' does not indicate any meaning different from the above". ${ }^{72}$ This was also, at least at that time, what international lawyers generally meant when using this term. ${ }^{73}$

69 See also the interpretative declarations of the Holy See and Paraguay, Report of the Fourth World Conference on Women, Beijing, 4-I5 September 1995,Addendum, Annex IV,UN Doc. A/CONF.I77/20/Rev.I, Chapter V, paragraphs 25 and II, available at <http://www.un.org/womenwatch/daw/beijing/pdf/Beijing\%2ofull\%2oreport\%2oE.pdf> (accessed 4 September 2014).

70 Art. 7(3) of the Rome Statute of the International Criminal Court.

$7^{7}$ See the Report of the UN Conference on Human Settlements (Habitat II), Istanbul, 3-I4 June I996 (Doc. GE.9602500, available at <http://daccess-dds-ny.un.org/doc/UNDOC/GEN/G96/025/o0/PDF/G9602500.pdf?OpenElement>, accessed 4 September 20I4). In particular see Annex V - recalled by Chapter III, Section D of the Habitat Agenda- where reference is made to the Statement on the Commonly Understood Meaning of the Term 'Gender' presented at the Fourth World Conference on Women by the President of the Conference, referred above.

72 See the Declaration of the World Conference against Racism, Racial Discrimination, Xenophobia and Related Intolerance, available at <http://www.un.org./WCAR/durban.pdf >, (accessed 4 September 20I4). Preamble, footnote, note I.

73 Among others, see H. Charlesworth, 'Gender and Governance in International Law', 5I Development Bulletin (2000) IO-I2, which at Io states: "The idea of 'gender' is typically understood by international lawyers as a synonym for 'women' and 'sex'." 
Something different happens when 'gender' is used and defined in international documents produced by 'experts', 'officers', 'bureaucrats', etc. ${ }^{74}$ In these cases, together with 'gender' definitions clearly adopting a 'static' vision of gender strongly reconnected to the two sexes, ${ }^{75}$ it is quite usual to find gender definitions based on social-theories. ${ }^{76}$

Nevertheless, it is not possible to attach any consequence to these definitions in order to reconstruct the ordinary meaning of the term 'gender' in a different way. Not only, indeed, they don't refer all to a socially-based definition, but also the ones that adopt such view define 'gender' in very different ways.

74 V. Oosterveld, 'The Definition of "Gender" in the Rome Statute of the International Criminal Court: A Step Forward or Back for International Criminal Justice?', I8 Harvard Human Rights Journal, (2005) 55-84, at 66-67 states: “There are two approaches within the United Nations to defining 'gender'. The first is a minimalist approach taken at the multilateral (state-negotiated) level Prior to the adoption of the Rome Statute definition, states basically left the term undefined, either overtly or implicitly. 'Gender' has been referred to without definition for over a decade in United Nations multilateral human rights documents, such as the outcome documents of some UN World Conferences and numerous resolutions from the Commission on Human Rights, Economic and Social Council, and General Assembly. [...] The second approach to defining 'gender', followed by the United Nations and its agencies, is quite different. These institutions have adopted a number of definitions of 'gender', some relatively detailed". Some examples of UN documents produced at the multilateral level and using 'gender' without defining it are: Implementation of the Nairobi Forward-Looking Strategies for the Advancement of Women, GA Res. 48/108, 20 December 1993, UN GAOR, 48th Sess., Agenda Item III, UN Doc. $\mathrm{A} / \mathrm{RES} / 48 / \mathrm{IO} 8$ (1994);Comprehensive Implementation of and Follow-Up to the Vienna Declaration and Programme of Action, UN ESCOR, Commission on Human Rights, 54th Sess., 58th mtg., UN Doc. E/CN.4/RES/1998/78 (1998);Women in Development, GA Res. 52/195, I8 December 1997, UN GAOR, 52d Sess., Agenda Item 50, UN Doc. A/RES/52/195 (1998); Rights of the Child, UN ESCOR, Commission on Human Rights, 55th Sess., 6oth mtg., UN Doc. E/CN.4/RES/1999/80 (1999); Elimination of Domestic Violence Against Women, GA Res. 58/147, 22 December 2003, UN GAOR, 58th Sess., Agenda Item IIO, UN Doc. A/RES/58/147 (2004); Strengthening of the Coordination of Emergency Humanitarian Assistance of the United Nations, UN ESCOR, Substantive Session of 2004, Agenda Item 5, UN Doc. E/2004/L.35 (2004).

75 The definition adopted by the World Bank, for example, states "women and men are different biologically but all cultures interpret and elaborate on these innate biological differences into a set of social expectations about what behaviours and activities are appropriate, and what rights, resources, and power they possess" (World Bank, Engendering Development Through Gender Equality in Rights, Resources and Voice, A World Bank Policy Research Report 2 (200I), available at <http://www.wds.worldbank.org/servlet/WDS_IBank_Servlet?pcont=details\&eid=000094946_oro20805393496> (accessed 4 September 2014); similarly, the Office of the Special Adviser on Gender Issues and Advancement of Women (hereinafter the 'OSAGI') states that 'gender' "refers to the social attributes and opportunities associated with being male and female and the relationships between women and men and girls and boys, as well as relations between women and those between men. These attributes, opportunities and relationships are socially constructed and are learned through socialization processes. They are context/time-specific and changeable. Gender determines what is expected, allowed and valued in a women or a man in a given context. In most societies there are differences and inequalities between women and men in responsibilities assigned, activities undertaken, access to and control over resources, as well as decision-making opportunities. Gender is part of the broader socio-cultural context. Other important criteria for socio-cultural analysis include class, race, poverty level, ethnic group and age" (OSAGI, Gender Mainstreaming, Concepts and Definitions, available at $<$ http://www.un.org/womenwatch/osagi/conceptsandefinitions.htm>, accessed 4 September 20r4).

${ }_{76}$ For example, the Guidelines on International Protection: Gender-Related Persecution Within the Context of Art. IA(2) of the 195I Convention and/or its 1967 Protocol Relating to the Status of Refugees, issued by the High Commissioner for Refugees, in 2002, (UN Doc. HCR/GIP/O2/or (2002)), in par. 3, in distinguishing between 'gender' and 'sex', reads "Gender is not static or innate but acquires socially and culturally constructed meaning over time"; similarly, the UN Special Rapporteur Gay J. McDougall, in her Report Contemporary Forms Of Slavery. Systematic rape, sexual slavery and slavery-like practices during armed conflict (UN Doc. E/CN.4/Sub.2/1998/13) quotes, in par. I8, a definition of Donna Sullivan, according to which "The term 'gender' refers to the socially constructed roles of women and men in public and private life. Gender is distinct from 'sex', which is biologically determined. (Donna Sullivan, Integration of Women's Human Rights into the Work of the Special Rapporteurs (New York: UNIFEM, 1996)". 
On the contrary, this strong dichotomy between the approach followed at the multilateral level and the one adopted by experts and agencies - i.e., on the one hand the frequent introduction of socially based definitions by means of documents written by the above mentioned experts and agencies and, on the other hand, the lack of any definition of this kind in documents voted and approved by states - shows that the attempt to introduce social theories of gender in International Law is often just a social engineering attempt, driven by ideologies that (being acceptable or not) clearly are not shared by states.

Moreover — and this makes the attempt just described even more dangerous - this lack of a univocal 'gender' definition also in the documents that opted for a socially-based approach is due to the fact that there is no agreement on the 'basic content of gender' even among those authors that push for the introduction of such a conceived definition, as more than one of them has clearly admitted. ${ }^{77}$

This lack of consent would be -in the opinion of these authors - at the origin of the nonintroduction of socially-based definition into treaties: even scholars who strongly believe in social gender theory and hope for its inclusion in binding legal instruments haveo admit that in order to do so "there would first need to be consensus among a group of states as to some of the basic content of 'gender', even when there is no agreement within the feminist community on the same point."78

Actually, what lacks is not an agreement among states on a basic content of 'gender'-as shown by the adoption of the referred definitions that seem to go in the same direction- but rather the states consensus for a socially-based definition of gender, always rejected when proposed for inclusion in a treaty, until the adoption of the Convention on preventing and combating violence against women and domestic violence.

By adopting a clearly socially based 'gender' definition, this treaty seems to break with the previous tradition and to impress a new course to 'gender' and related issues in International Law. Nevertheless, a non-superficial study of its text and of its negotiations history surprisingly shows that, in fact, the Istanbul Convention itself goes towards the same direction of the other legally binding instruments.

First of all, it is significant to recall that the Draft Convention was not prepared by a Conference of States but rather by a 'group of experts', 79 to whom the wording of such a definition has to be attributed.

Secondly - as referred above - this definition is just mentioned in Article 3 and never recalled or directly used in the text of the treaty, which from the other hand revealed a lot of problems that

7 Among others, see Oosterveld supra n. 46, who explicitly states, at 73, "Within feminist theory, including feminist theory of international law, there are evolving and differing views on the nature of 'sex' and 'gender' " and she ascribes certain aspects of the lost opportunity due to the introduction of a strong socially based definition in the Rome Statute to these differences.

${ }_{78} \quad$ Ibid., at 83 .

79 See the appointment of the "Ad Hoc Committee on Preventing and Combating Violence Against Women and Domestic Violence (CAHVIO)" by the Ministers' Deputies at their I044th meeting, held in Strasbourg on Io December 2008, available at <https://wcd.coe.int/ViewDoc.jsp?id=I43908I\&Site=CM> (accessed 4 September 20I4). 
catalysed the attention of the states ${ }^{80}$ in the very short time they had to discuss and approve the final text of the Convention. ${ }^{8}$ This notwithstanding, states expressed their concern about this definition, discussed on it and tried to have it removed from the final text or to have it changed with a definition conceived like the one contained in the Rome Statute. ${ }^{82}$

Thirdly, the decision to adopt the text of the Convention without a vote f $^{8_{3}}$-for the very first time in the history of Council of Europe conventions! - , due to both the pressure of a short time available and to the political reason specified immediately below, barred this aspiration of many of the states involved. However, they modified the Draft Explanatory Memorandum, by adopting a much more cautious perspective, very far from social theories: "In the context of this Convention, the term gender, based on the two sexes, male and female, explains that there are also socially constructed roles, behaviours, activities and attributes that a given society considers appropriate for women and men." ${ }^{4}$

In particular, the wording "the term gender, based on the two sexes, male and female" - added during the negotiation preliminary to the signature ${ }^{85}$ - brings the meaning of 'gender' much more closer to the Rome Statute definition, according to which "the term 'gender' refers to the two sexes, male and female, within the context of society", as recalled above. This way, indeed, the states parties unambiguously reconnected 'gender' to 'sex' and in particular to 'the two sexes', thus recognizing the role of society in constructing roles, but only in the framework of two given and static sexes: male

8o For a first approach into the problematic issues of the Draft Convention (and the Convention itself, having been the draft text approved without a vote and so without any modification) and into the amendments proposed by states, see Amnesty International Public Statement Proposed changes will undermine new European treaty on violence against women (I.N. IOR 6I/ooI/2OII), available at <http://www.amnesty.org/en/library/info/IOR6I/ooI/20II/en> (accessed 4 September 2014) and the Report Time to take a stand: Amnesty International opposes amendments that will weaken the Council of Europe treaty on violence against women (IN IOR 6I/004/20II), presented on March 20II by Amnesty International and available at <http://www.amnesty.org/es/library/info/IOR6I/o04/20II/en> (accessed 4 September 20I4). See also the Opinion 280(20II) of the Parliamentary Assembly of the Council of Europe on the Draft Convention on preventing and combating violence against women and domestic violence, available at <http://assembly.coe.int/Main.asp?link=/Documents/WorkingDocs/Docir/EDOCi2530.htm\#PI5_I58> (accessed 4 September 20I4). With this Document the Parliamentary Assembly of the Council of Europe (PACE) proposed a long series of amendments in relation with many of the articles of the Convention, including Art. 3.

${ }_{8} \quad$ On this point, see above, in this section.

82 For example, the Russian Federation considered the removal of Paragraph (c) of Art. 3 of fundamental importance because, according to the Russian Government, the definition of 'gender' contained in it gave a far too broad and ambiguous interpretation of the Convention's subject matter and eroded its scope of application. For example, it would allow anyone (including men) who 'consider' themselves a woman to claim rights reserved by the Convention for women. Affirming that the terms 'gender' and 'sex' are absolute synonyms, the Russian Government asked to use the term gender according to the meaning in was given in the other international human rights instruments currently in force and to interpret and apply the terms 'woman' and 'gender identity' in their literal meaning. Also Bulgaria claimed for a new formulation of Art. $3(\mathrm{c})$ in order to bring the 'gender' definition in line with the one contained in the Rome Statute, namely "the term 'gender' refers to the two sexes, male and female, within the context of society. The term 'gender' does not indicate any meaning different from the above". Having been confronted with strong opposition to the reopening of the discussion on the Draft Convention, the proposed amendments, lead only to some modifications of the Explanatory Report.

83 See the Decision adopted by the Ministers Deputies during the inith meeting, held in Strasbourg, 6-7 April 20II, $\mathrm{CM} / \mathrm{Del} / \operatorname{Dec}(201 \mathrm{I})$ IIII, available at <https://wcd.coe.int/ViewDoc.jsp?id=I773137\&Site=CM $>$ (accessed 4 September 20I4).

${ }^{8} 4$ See Paragraph 43 of the Explanatory Report. Compare it with the same Paragraph as proposed in the Draft Explanatory report: see <http://www.coe.int/t/dghl/standardsetting/violence/CAHVIO\%20_20II_\%207\%20FIN_en.pdf> (accessed 4 September 2014).

85 Compare the final version of the Explanatory Report with the Draft Explanatory Report elaborated by CAHVIO (Doc. CAHVIO_2OII_ 7 FIN_en), available at ibid. 
and female. The definition contained in Article 3 (c) has to be read through the interpretation offered by Paragraph 43 of the Explanatory Report.

Finally, it could be useful to bear in mind the political framework in which the Convention was adopted: some governmental and non-governmental institutions strongly urged for its adoption in a very short time limit. The haste that led to the adoption of a problematic and contradictory definition, as well as to a Convention full of points perceived as (even more) problematic by states parties, was due among other reasons to the fact that the Turkish Government wanted at any cost to open the Convention for signature at the closure of its chairmanship of the Committee of Ministers, ${ }^{86}$ thus 'transforming' the Convention on preventing and combating violence against women and domestic violence into the 'Istanbul Convention'. This way, Turkey acquired a key diplomatic success to offer to the European Union, in order to demonstrate its own commitment for the promotion and protection of human rights - women rights in particular - especially in view of its future access to the EU. On the other hand, some other Governments sacrificed the possibility to spend some time in order to modify the Draft of the CAHVIO, to achieve the realization of different diplomatic goals.

In order to achieve these goals, the discussion between the states involved was forced into very short time-borders during which they had to face all the relevant problems raised by the text of the treaty, discussing on the amendments and trying to find agreement on those very sensitive issues dealt in it. This hurry led to the adoption of the text of the Conventionwithout a vote, and states were forced to intervene on 'gender' definition by modifying the Explanatory Report rather than Article 3 of the Convention. This led also the states to adopt a document that, although having been prepared by experts, is full of problems and contradictions, 'gender' definition being only one of them. Among other issues, in fact, such a conceived definition opens the door to uncertainty and cascading effects on international obligations of states parties of this Convention.

\section{THE DANGER OF UNPREDICTED AND SERIOUS INTERNATIONAL RESPONSIBILITY FOR STATES PARTIES}

This 'undefined definition' of 'gender' provided by Article 3 (c), while adding nothing to women's protection, brings many risks for the Parties, opening the door for incalculable sources of state responsibility and has delayed the entry into force of an important Convention.

First of all, the hasty adoption of the definition leads to severe interpretative problems related to the concept of 'gender' itself. As shown above, in fact, a strongly socially-based definition is authentically interpreted by the Explanatory Report in a more classical way, with a strong and direct reference to typically biologically-based elements. How to interpret the mix of such dichotomous elements? To what extent the authentic interpretation - whose re-drafting was strongly wanted by

86 See the Decision adopted by the Ministers' Deputies, at their Iorith meeting of 6-7 April 20II, available at <https: //wcd.coe.int/ViewDoc.jsp? Ref=CM/Del/Dec(20II)III/Io.4\&Language=lanEnglish \&Ver=original $\&$ Site $=\mathrm{COE} \& B a c k$ ColorInternet=DBDCF2\&BackColorIntranet=FDC864\&BackColorLogged=FDC864\#RelatedDocuments $>\quad$ (accessed 4 September 2014). 
states - will influence the definition drafted by experts and approved by states Parties without a vote, as it was for the Convention?

Secondly, a bad drafting of the whole Convention leads to a serious confusion on the effects of the definition in the framework of the treaty itself, thus opening the door to serious incertitude. Such a consequence is evident, for example, with respect to Article 4, Paragraph 3 of the treaty itself. This provision commendably imposes the states parties to implement the provisions of the Convention, particularly its measures to protect the rights of the victims, without any discrimination on such grounds as race, colour, language, religion, etc. Nevertheless, in reading this provision, it is really surprising to realize that states parties are bound to secure the implementation of the provision of the "Convention on preventing and combating violence against women and domestic violence", also without any discrimination based on sex and gender...!

Such an obligation appears even more astonishing if one considers the relevance assigned to 'sex' and 'gender', listed as the first non-discrimination grounds for the implementation of norms conceived almost exclusively for women protection. ${ }^{87}$ How should this provision be interpreted?

Article 4, Paragraph 3 - which at first sight could appear bizarre and senseless - becomes full of significance if read bearing in mind all the theories from which the social definition of gender stems and the goals pursued by them. Moreover, this interpretation is clearly confirmed by Paragraph 53 of the Explanatory Report, which extends, in an almost explicit way, the protection against 'women violence' also to people that (having regard to their sex) are not women... ${ }^{88}$ In the same way, during the discussion on the Draft Convention, some similarly serious doubts have been raised by states on the interpretative effects that a definition conceived this way could have on other provisions of the treaty. ${ }^{89}$

${ }_{87}$ In particular, it seems not persuasive to interpret this part of Art. 4, Paragraph 3 as limited to the protection of men and children who are victims (or witnesses, as regarding children) of domestic violence, according to Art. 2, Paragraph 2. What leads to this conclusion are: the lack of any expression limiting the two above mentioned non-discrimination grounds to victims of domestic violence; the absolute marginality of provisions regarding men and children who are victims or witnesses of domestic violence in the context of the whole Convention, especially if compared with the centrality of the provision contained in Art. 4 and with the lack of any reference to a limitation eventually conceived this way in an article with such a broad objective; and the absolute absence of any clarification in this sense in the Explanatory memorandum (Paragraphs 52-54). Similarly, it seems not persuasive to interpret this provision as referring just to the 'gender identity' perceived by a woman because Art. 4, Paragraph 2 also includes an express reference to this different ground of possible discrimination. Moreover, see in particular what is said infra, in this section, about Paragraph 53 of the Explanatory Report and n. 88 .

88 In commenting Art. 4, Paragraph 3 of the Convention - i.e. in explaining the reason of the inclusion of 'sex' and 'gender', among others, as non-discrimination grounds for the implementation of the provision of this Convention Paragraph 53 of the Explanatory Report affirms: "Certain groups of individuals may also experience discrimination on the basis of their gender identity, which in simple terms means that the gender they identify with is not in conformity with the sex assigned to them at birth. This includes categories of individuals such as transgender or transsexual persons, crossdressers, transvestites and other groups of persons that do not correspond to what society has established as belonging to 'male' or 'female' categories".

89 In this context, the Committee of Legal Advisers on Public International Law ('CAHDI') of the Council of Europe has been asked to clarify if the gender definition contained in Art. 3 (c) fully corresponds with the definition of 'genderbased violence against women' as "violence that is directed against a woman because she is a woman" and if it could be possible for a man acting outside the socially constructed masculine roles and behaviors, and fitting instead into the feminine roles and behaviors, to be considered as falling under the definition of the female gender and, oppositely, if a woman acting outside the socially constructed feminine roles and behaviors, and fitting instead into the masculine roles and 
This shows once again that Article 3 (c) and related provisions deal really little - if not at allwith women protection against violence, while affecting other relevant problems in a very significant way. $9^{\circ}$ Going beyond the single provisions, introducing these striking consequences stealthily, by a back-door, taking advantage of a treaty devoted to such serious — and very different- problems is a matter of a great gravity, because of the lack of an international consent on such a definition, of the theories by which it stems (which not necessarily are shared by states) and of the consequences of political and juridical nature indirectly introduced in national law for states parties.

Similarly, the confusion generated by the said 'gender' definition in the framework of the treaty itself and the incertitude caused by it can affect the work of the above referred "Group of experts on actions against violence against women and domestic violence" ${ }^{91}$ and, this way, produce relevant consequences in the national systems of the Parties of the Convention.

According to Chapter IX of the Convention, the Parties have endowed the Group with powers to monitor its implementations. Among others, it will be entrusted with the preparation of the questionnaires to be addressed to states parties, which shall respond to them in drafting their reports; ${ }^{22}$ it will adopt reports and conclusions on the measures taken by the Parties concerned to implement the Convention;93 it will conduct inquiries and organize country visits ${ }^{94}$ and adopt general recommendations for the implementation of the treaty.95

It is easy to understand how a monitoring of the application of the Convention eventually oriented by the said 'gender' definition and by the theories from which the social definition of gender stems could have a broad and deep influence in the national juridical systems of states parties. In fact, in monitoring its implementation, GREVIO will interpreter the various provision of the Convention and will evaluate states parties behavior in this light, making proposals and suggestions on the implementation itself. A couple of elements, in particular, make one fear a high risk that the 'undefined definition' of 'gender' provided by Article 3 (c) could influence the work of GREVIO, being source of confusion in its interpretation and application of the convention. I refer, in detail, to the fact that GREVIO will be composed by 'experts'96 and that it has been endowed with the power to "receive information on the implementation of the Convention from non-governmental organizations and civil society". 97

The fact that GREVIO will be composed by independent expert - like any monitoring body seriously endowed with monitoring powers - is of the utmost importance. On the other hand, praxis related with the use of the term 'gender' by 'experts' and its deep incongruences have been commented above..$^{98}$

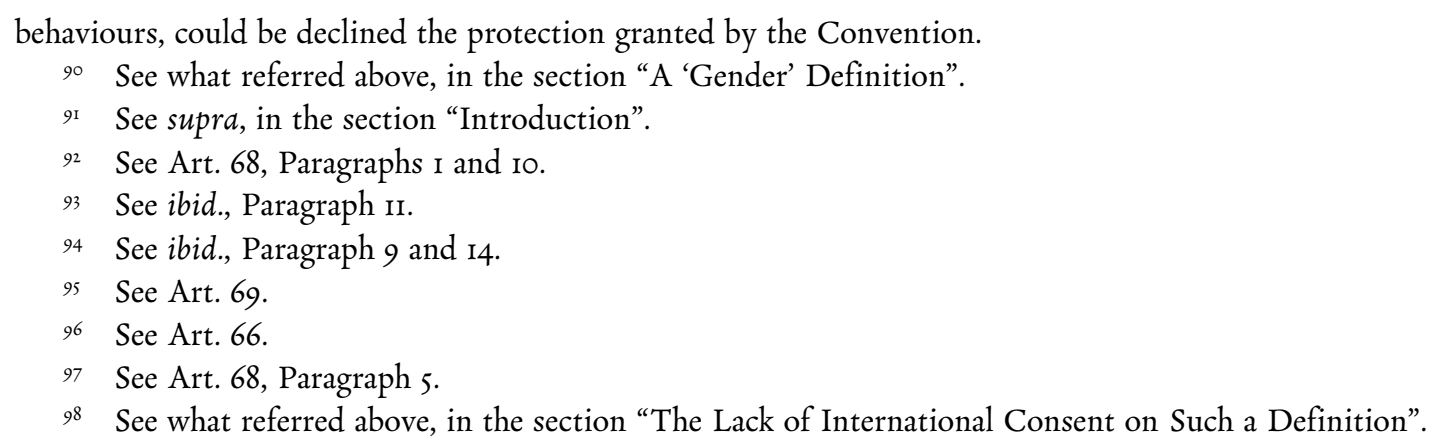


As to the involvement of non-governmental organization and civil society, it has to be warmly welcomed as an important mean that will strongly contribute at the implementation of the Convention and at a complete and detailed monitoring by GREVIO. On the other hand, it is easy to argue that in such a sensitive and complex field involving 'gender' theories, some non-governmental organizations most likely will try to force the ambiguous interpretation of the 'term' contained in Article 3, in order to lobby their own particular vision on such issue, in one sense or the other. All this will probably influence the work of this monitoring body and through its questionnaires, reports, conclusions and general comments, the effects of this new and complex 'gender' definition could probably enter the 'borders' of national systems of states parties through a back-door.

Thirdly, bearing in mind the wide number and variety of socially-based 'gender' conceptions ${ }^{99}$ and the lack of any consent even among scholars adopting this perspective, ${ }^{\text {Ioo }}$ it is easy to understand how unclear the obligations flowing for states parties from the adoption of the definition contained in Article 3 are, and how unpredictable the other consequences coming from it could be.

On one hand, these consequences - with an incalculable scope- could gradually affect the interpretation of all the great number of international norms recurring to the term 'gender'. The introduction of a new definition of this concept in International Law could in some way contribute to an interpretative evolution of many international norms, whose meaning and scope would be reformulated and expanded beyond any prevision, because of the deep qualitative change in the meaning of the term. This would be possible because of the lack of a 'gender' definition in most of the treaties containing these norms; because of the very little number of 'gender' definition that are legally binding in International Law; and, as a consequence, because of the relatively strong weight that Article 3 definition would have.

On the other hand, acting directly - because of its own force, in the framework of the Istanbul Convention - and indirectly trough the channels referred above, by allowing the back-door dissemination of the underlying theories, such a conceived definition is capable to unbar the door, in each of the states parties, to the introduction of theories such as the "impossibility of any fixed identity", ${ }^{\text {ror }}$ which brings inevitably to the idea of "the limits of politics conducted strictly around issues of sexual identity". ${ }^{\text {Io2 }}$

Such a definition, for example, could be interpreted in the long or medium term as criminalizing every national law or policy that simply treats differently heterosexual marriage over homosexual couples, on the grounds that homosexuality is a recognized 'gender' like maleness and femaleness and consequently such discrimination is unjustified, or on the grounds of the juridical irrelevance of gender and sex. Similarly, some serious interpretative problems would inevitably rise when applying national and international norms - even European Union ones - dealing with 'gender balance' or claiming for ensuring 'gender perspective' in various policies. By admitting the existence of more than two genders, will states be bound to introduce new quotas in order to respect equality? If yes, how

99 See above, ibid.

roo See above, the section "The Lack of International Consent on Such a Definition".

ror Grigolo supra n. 2I, at 1025.

I02 Ibid., at I026. See above, the section "A 'Gender' Definition”. 
many new quotas are to be introduced in national law: one for each gender, or just one (or more than one) for the weakest one(s) among them? And how to ascertain which gender a person belongs to, for the purpose of admitting him/her to the participation to a quota, not taking into account his/her sex? And what about gender quotas if, like the more advanced social theories of gender claim, the idea that there is only one gender will be accepted?

One might think that this could be an exaggerated, almost futuristic scenario, but if we look to some of the laws recently introduced in more than one national system, we can find some examples of the consequences flowing from the adoption of this perspective. Just to quote the most relevant ones, we can refer to those national laws that opened the way to gender change by a simple declaration and apart from any surgical sex change, sometimes referring to this modification as 'sex change'. These kind of legislations have been recently introduced for example in the United Kingdom (Gender Recognition Act 2004), ${ }^{103}$ Portugal (Cria o procedimento de mudança de sexo e de nome próprio no registo civil e procede à décima sétima alteração ao Código do Registo Civil), ${ }^{104}$ Spain (Ley reguladora de la rectificación registral de la mención relativa al sexo de las personas), ${ }^{\text {ros }}$ Argentina (Ley de identitad de Género), ${ }^{106}$ and Uruguay (Derecho a la identidad de género y al cambio de nombre y sexo en documentos

${ }^{103}$ See <http://www.legislation.gov.uk/ukpga/2004/7/pdfs/ukpga_20040007_en.pdf> (accessed 4 September 2014). Art. 9, Par. I of the Gender Recognition Act states: "Where a full gender recognition certificate is issued to a person, the person's gender becomes for all purposes the acquired gender (so that, if the acquired gender is the male gender, the person's sex becomes that of a man and, if it is the female gender, the person's sex becomes that of a woman)". Among the requirements to change gender (and sex) the Gender Recognition Act does not mention any sex modification (see Arts. I-3).

${ }^{104}$ Lei n. ${ }^{0}$ 7/20II of 15 March 20II, Diário da República, I.a série, No. 52 (see $<$ http://dre.pt/pdfrsdip/2011/03/05200/0145001451.pdf>, accessed 4 September 2014). This law "regula o procedimento de mudança de sexo no registo civil e correspondente alteração de nome próprio", following a simple application of the citizen and an attached certification attesting gender disorder. The law does not require any medical interventions for the legal recognition of a sex change.

105 Ley 3/2007, of I5 March 2007 (see <http://www.boe.es/buscar/doc.php?id=BOE-A-2007-5585>, accessed 4 September 20I4). Art. 4 of the Ley states: "Requisitos para acordar la rectificación. I. La rectificación registral de la mención del sexo se acordará una vez que la persona solicitante acredite: a. Que le ha sido diagnosticada disforia de género. La acreditación del cumplimiento de este requisito se realizará mediante informe de médico o psicólogo clínico, colegiados en España o cuyos títulos hayan sido reconocidos u homologados en España, y que deberá hacer referencia: I. A la existencia de disonancia entre el sexo morfológico o género fisiológico inicialmente inscrito y la identidad de género sentida por el solicitante o sexo psicosocial, así como la estabilidad y persistencia de esta disonancia. 2. A la ausencia de trastornos de personalidad que pudieran influir, de forma determinante, en la existencia de la disonancia reseñada en el punto anterior. b. Que ha sido tratada médicamente durante al menos dos años para acomodar sus características físicas a las correspondientes al sexo reclamado. La acreditación del cumplimiento de este requisito se efectuará mediante informe del médico colegiado bajo cuya dirección se haya realizado el tratamiento o, en su defecto, mediante informe de un médico forense especializado. 2. No será necesario para la concesión de la rectificación registral de la mención del sexo de una persona que el tratamiento médico haya incluido cirugía de reasignación sexual. Los tratamientos médicos a los que se refiere la letra b del apartado anterior no serán un requisito necesario para la concesión de la rectificación registral cuando concurran razones de salud o edad que imposibiliten su seguimiento y se aporte certificación médica de tal circunstancia".

${ }_{106}$ Ley 26.743, promulgated on 23 May 2012 (see <http://infoleg.mecon.gov.ar/infolegInternet/anexos/195000199999/197860/norma.htm>, accessed 4 September 2014). Art. 4, in settling the requirements for changing the sex indicated in public registers, states: "Requisitos. Toda persona que solicite la rectificación registral del sexo, el cambio de nombre de pila e imagen, en virtud de la presente ley, deberá observar los siguientes requisitos: I. Acreditar la edad mínima de dieciocho (I8) años de edad, con excepción de lo establecido en el artículo $5^{\circ}$ de la presente ley. 2. Presentar ante el Registro Nacional de las Personas o sus oficinas seccionales correspondientes, una solicitud manifestando encontrarse amparada por la presente ley, requiriendo la rectificación registral de la partida de nacimiento y el nuevo documento nacional de identidad correspondiente, conservándose el número original. 3. Expresar el nuevo nombre de pila elegido con el que solicita inscribirse. En ningún caso será requisito acreditar intervención quirúrgica por reasignación genital total o parcial, ni acreditar terapias 
identificatorios), ${ }^{107}$ while in other states, like The Netherlands, similar norms are under discussion in public opinion. ${ }^{\mathrm{I} 8}$

Most of these laws set up a public register where people can annotate their new gender, so changing their gender and often also their sex ${ }^{109}$ just by declaring it to the register official. Some of the referred regulations don't fix any age-limits, nor forbid any further future change. ${ }^{\text {Io }}$

Similarly, following social gender theories, some states have introduced a third gender in their normative systems. For example, Australia introduced an ' $\mathrm{X}$ ' as a third option, together with ' $\mathrm{F}$ ' and

hormonales u otro tratamiento psicológico o médico". Art. 5 of Ley 26.743 regulates also gender changes for children under the age of 18 .

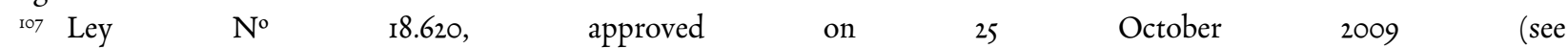
<http://sip.parlamento.gub.uy/leyes/AccesoTextoLey.asp?Ley=18620\&Anchor=>, accessed 4 September 20I4), whose Art. 3 states: "(Requisitos).- Se hará lugar a la adecuación registral de la mención del nombre y en su caso del sexo toda vez que la persona solicitante acredite: I) Que el nombre, el sexo -o ambos- consignados en el acta de nacimiento del Registro de Estado Civil son discordantes con su propia identidad de género. 2) La estabilidad y persistencia de esta disonancia durante al menos dos años, de acuerdo con los procedimientos establecidos en la presente ley. En ningún caso se exigirá cirugía de reasignación sexual para la concesión de la adecuación registral de la mención del nombre o del sexo que fuere disonante de la identidad de género de la persona a que se hace referencia en dicho documento. Cuando la persona haya procedido a la cirugía de reasignación sexual, no le será necesario acreditar el extremo previsto en el numeral 2) del presente artículo”. No minimum-age requisite is provided by the law.

${ }^{108}$ See the Report "Controlling Bodies, Denying Identities. Human Rights Violations against Trans People in the Netherlands", edited by Human Rights Watch in 20II and available electronically at <http://www.hrw.org/sites/default/files/reports/netherlandsogirwebwcover.pdf>, accessed 4 September 20I4. Some of the proposed amendments to the law relate to gender changing without any sex change (see page. 7 of the Report) nor any statement signed by certified experts confirming an enduring conviction that the person asking for gender change belongs to the gender opposite to that assigned at birth: primacy would be afforded to trans people's own self-defined gender identity (ibid.); it would be allowed to change their legal gender also during the childhood (see page 69 of the Report); should be "recognize the existence of gender variant people whose gender identity is neither exclusively female nor exclusively male" (see page 8 of the Report).

${ }_{109}$ For example, Art. 5 of the referred Spanish Law states: "I. La resolución que acuerde la rectificación de la mención registral del sexo tendrá efectos constitutivos a partir de su inscripción en el Registro Civil. 2. La rectificación registral permitirá a la persona ejercer todos los derechos inherentes a su nueva condición. 3. El cambio de sexo y nombre acordado no alterará la titularidad de los derechos y obligaciones jurídicas que pudieran corresponder a la persona con anterioridad a la inscripción del cambio registral"; Art. 7 of the referred Argentinian Law, Parr. I and 2 states "Efectos.Los efectos de la rectificación del sexo y el/los nombre/s de pila, realizados en virtud de la presente ley serán oponibles a terceros desde el momento de su inscripción en el/los registro/s. - La rectificación registral no alterará la titularidad de los derechos y obligaciones jurídicas que pudieran corresponder a la persona con anterioridad a la inscripción del cambio registral, ni las provenientes de las relaciones propias del derecho de familia en todos sus órdenes y grados, las que se mantendrán inmodificables, incluida la adopción”; Art. 5 of the Uruguayan one : "(Efectos).- I) La resolución que autorice la rectificación de la mención registral del nombre y en su caso del sexo, tendrá efectos constitutivos a partir de la fecha en que se haga efectivo dicho cambio en la partida de nacimiento. Frente a terceros, la inscripción del acto que corresponda registrar en la Dirección General de Registros, será oponible a partir de la fecha de su presentación al Registro. 2) En ningún caso alterará la titularidad de los derechos y obligaciones jurídicas de la persona cuyo registro se modifica ni será oponible a terceros de buena fe. 3) El cambio registral del sexo permitirá a la persona ejercer todos los derechos inherentes a su nueva condición. 4) A los efectos registrales, el cambio de cualquier dato que incida en la identificación del sujeto conforme a esta ley, no implicará el cambio de la titularidad jurídica de los actos inscriptos en la Dirección General de Registros. A estos efectos, el Registro siempre considerará la rectificación como un acto modificativo que deberá vincularse con la inscripción anterior”.

no Art. 8 of the referred Argentinian Law, for example, expressly regulated the subsequent changes, with the only additional requisite of a judicial authorization: "La rectificación registral conforme la presente ley, una vez realizada, sólo podrá ser nuevamente modificada con autorización judicial”; the Uruguayan one, at Art. 4, Par. 2 states "Producida la adecuación registral, ésta no podrá incoarse nuevamente hasta pasados cinco años, en cuyo caso se vuelve al nombre original"; the Law do not forbid any subsequent rectification. 
'M', in its passport policy. ${ }^{\text {III }} \mathrm{Nepal}$, starting from September 2008, registers people asking for it and without any other formality, as 'third-gender' in issuing national ID cards. Since 2010 the Nepal Election Commission has allowed citizens to register to vote as a third gender (based entirely on selfidentification), while a 'third sex' option was introduced by the same Government on the 2or federal census. ${ }^{\mathrm{II} 2}$ Similarly also India, starting from 2005 , introduced a third gender registration (indicated with ' $E$ '). Even in this case we have an identity-based category,requiring no proof or medical surgery. The same state added, in 20II, a 'third gender' census option. ${ }^{\mathrm{II} 3}$ The introduction of a third gender option has been under discussion in Germany ${ }^{14}$ and, very recently, $\ 22$ III of the Personenstandsgesetz has been introduced, allowing newborns to be registered keeping their gender undefined on their birth certificates: ${ }^{115}$ if on the one hand a 'third gender' has not officially been introduced, on the other hand it is possible to argue that people registered as "undetermined sex" will have to have their own peculiar separate status in legal matters recognized in the future.

Whatever opinion one may have about the goodness or not of such juridical openings, what the author of this study wants to strongly underline is that all of these issues go beyond a convention on preventing and combating violence against women and domestic violence and should have been set aside. This is a further reason why, the best way to deal with such delicate and important matters, would have been to discuss them in the framework of a specific convention. Such delicate and deep concepts, full of consequences flowing from the choice of a 'gender' definition, in fact, shouldn't be forced through a back-door, while discussing and approving distinct and - at last - equally important matters.

Of course, this would cause quite strong changes in the politics of most of the 47 member states of the Council of Europe, which will have to face unexpected ${ }^{\mathrm{II}}$ and, to some extent, unpredictable

II See Australian Passport Office, Sex and Gender Diverse Passport Applicants: Revised Policy, available at <https://www.passports.gov.au/web/sexgenderapplicants.aspx> (accessed 4 September 20I4). Even though the X category is denoted as "indeterminate/unspecified/intersex", this administrative measure clearly opens to a non-male-nor-female gender category. The Revised policy also allows people to receive a passport in "their preferred gender" without any sex reassignment surgery. Furthermore, the Sex Discrimination Amendment (Sexual Orientation, Gender Identity and Intersex Status) Act 2013 (Act No. 98 of 2013, see <http://www.comlaw.gov.au/Details/C2013Aooo98>, accessed 4 September 20I4), in amending the Sex Discrimination Act 1984, introduced the definitions of 'gender identity' (Paragraph 6) and 'intersex status' (Paragraph 7), while at the same time repealing form the Sex Discrimination Act 1984 the definitions of 'man' (Paragraph 8) and 'woman' (Paragraph 14). Similarly, the 1984 Act was amended, in the same circumstance, by substituting any reference to 'the opposite sex' with 'a different sex' (see Paragraphs $16,36,42,47$ ) and any reference to 'the opposite sex to', with 'a different sex from' (see Paragraphs 16, 36, 42 and 47 of the above mentioned 2013 Act).

II See Central Bureau of Statistics, National Population Census 20II-Nepal, House/Household Listing Form (20II), available at <http://www.census.gov.np/images/pdf/HHListing\%2oFormEng.pdf> (accessed 4 September 20I4). See also M. Bochenek and K. Knight, 'Establishing a Third Gender Category in Nepal: Process and Prognosis', 26, 3 Emory International Law Review (2012) II-42 (available at <http://www.law.emory.edu/fileadmin/journals/eilr/26/26.I/Bochenek_Knight.pdf> (accessed 4 September 20I4), at 3I and ff.

II3 See ibid., at 29-30.

${ }^{114}$ See Arts. I, 2 and 5 of the Gesetz über die Wabl oder Änderung der Vornamen und die Feststellung der Geschlechtszugebörigkeit (Transgendergesetz TrGG), available at <http://www.transmann.de/transinfo/pgg-trgg.htm> (accessed 4 September 20I4).

Is Gesetz zur Änderung personenstandsrechtlicher Vorschriften (Personenstandsrechts-Änderungsgesetz - PStR ÄndG) of 7 May 2013 (BGBl. I S. II22) entered into force on I November 2013.

I16 For example, detailed information about the legal frameworks in each of the 27 states being part of the European Union can be found in the country background studies that were prepared for a 2010 report by the European Union Agency 
problems and responsibilities, from both a juridical and a political point of view, if these relevant issues are not directly negotiated and consciously adopted by states. Indeed, states ratifying this Convention - or similarly conceived ones - not being conscious of the problems stemming from this definition, could very soon be faced with extremely important and unexpected concerns dealing with gender definition, which could be source of international responsibility.

In this respect, it could be of some interest to very briefly take into consideration the attitude shown by European Court of Human Rights (hereinafter the 'ECHR') when dealing with 'gender' and related issue and to try to ponder the possible impact of the newly introduced definition on future decisions of the Court itself.

A study of its case law points out that the ECHR makes a quite broad use of the term 'gender'. ${ }^{\text {II }}$ Furthermore it seems that for a long time it endorsed a biological' perspective: when referring to 'gender', 'transgender' etc., it used these words in a interchangeable way in respect with the term 'sex', 'transsexual', etc.

Nonetheless this lead to some 'un-thechnicalities' ad related confusion in the case law of the Court. Very often, for example, the Court used alternatively the words 'sex' and 'gender' or the words 'transgender' and 'transsexual', referring to people having undergone medical surgery to have their sex reassigned, even in very recent judgments. ${ }^{\mathrm{II}}$ Besides, in using 'gender' as a synonymous of 'sex' and making gender change depend on a (total or partial) surgical modification of the external characters of the sex itself, the Court used also very equivocal expressions like "gender reassignment surgery" .ir

On the other hand, starting from its decision in the Goodwin case ${ }^{\mathrm{I2}}$, the Court took some distance from its previous case law, always linking gender with sex, intended in its purely biological nature. ${ }^{22} I n$ Goodwin, the ECHR took the "sexual identity chosen" by individuals ${ }^{122}$-another equivocal expression - into consideration and affirmed that "while it also remains the case that a transsexual cannot acquire all the biological characteristics of the assigned sex (Sheffield and Horsham, cited above, p. 2028, \56), the Court notes that with increasingly sophisticated surgery and types of hormonal treatments, the principal unchanging biological aspect of gender identity is the chromosomal element" ${ }^{\prime 23}$ and that "it is not apparent to the Court that the chromosomal element, amongst all the others, must inevitably take on decisive significance for the purposes of legal attribution of gender identity for transsexuals." The Court so concluded "a test of congruent

for Fundamental Rights (FRA): "Homophobia, Transphobia and Discrimination on Grounds of Sexual Orientation and Gender Identity. 2010 Update. Comparative Legal Analysis”, Luxembourg, 20I0, at $<$ http://fra.europa.eu/fraWebsite/attachments/FRA-LGBT-report-update-corr2oIo.pdf > (accessed 4 September 20I4).

${ }_{\text {II }}$ According to the database of the Court (<http://hudoc.echr.coe.int/>, accessed 4 November 2014), the ECHR used the word 'gender' or derived words in such 189 decisions.

I8 See, among others, Hämäläinen v. Finland (Application no. 37359/09) I6 July 2014, paragraphs 32, 68; and L. v.Lithuania (Application no. 27527/03)Judgment in September 2007, final 31/03/2008, paragraph 7.

I1 See, among others, L. v. Lithuania, supra n. II7, paragraphs 25, 58, 59 and 64; or Hämäläinen v. Finland, supra n. II7, paragraphs I0, 19, 32, 58, 68, 80.

${ }^{120}$ Christine Goodwin v. the United Kingdom (Application no. 28957/95)judgment II July 2002.

${ }^{22}$ See S. Sanz-Caballero, 'El Tribunal Europeo de Derechos Humanos y su respuesta al reto de la transexualidad: historia de un cambio de criterio', 29, 4, American University International Law Review (2014) 831-868.

${ }^{122}$ Christine Goodwin, supra n. 120, paragraph 91.

${ }^{123}$ Ibid., paragraph 82. 
biological factors can no longer be decisive in denying legal recognition to the change of gender of a post-operative transsexual. There are other important factors: the acceptance of the condition of gender identity disorder by the medical professions and health authorities within Contracting States, the provision of treatment including surgery to assimilate the individual as closely as possible to the gender in which they perceive that they properly belong and the assumption by the transsexual of the social role of the assigned gender." ${ }^{224}$

This way, the ECHR — far from definitively splitting gender from sex - at any rate softened its position on this issue: the assumption of the social role of the assigned gender by the transsexual, summed to some physical modification in the external sexual attributes is able to overcome the persistence of other unchanging biological aspects related with sex. ${ }^{125}$ However, on the other hand, the reasoning of the Court always moves in the framework of a two-gender and two-sex conception and of the need to modify body sexual characteristics as far as possible in order to achieve gender change.

In conclusion, the concepts adopted by the ECHR when dealing with issues related with gender and sex and their definition - in particular in its latest case law- remain to some extent unclear and open to a future broad evolution in one way or another, towards a more 'social' or biological' orientation of the issue. The decisions adopted in Goodwin and the following case law seem to show an orientation towards a weakening of the biological elements, for the benefit of a more socialoriented conception of 'gender'.

The adoption of the Convention on preventing and combating violence against women and domestic violence, containing the said 'gender' definition together with the broad and deep interpretative problems referred above seams able to influence, among others, the future case law of the ECHR, very likely towards a more social-oriented approach to the concept of gender. The consequences flowing from it for member states' internal systems would be of the utmost relevance.

The above referred are just some of the possible future consequences affecting the national systems and flowing from the adoption of the 'gender' definition contained in Article $3(\mathrm{c})$ of the Istanbul Convention.

On the other hand - what is worse- being aware of these problems, states could decide to oppose the implementation of this Convention in their own national law, in order to avoid problems of this kind, so determining a great debacle for women's rights protection.

\section{CONCLUSION: A PARTIALLY FAILED ATTEMPT}

The 'gender' definition contained in Article 3 (c) of the Convention on preventing and combating violence against women and domestic violence can be regarded as a real novelty in International Law, since - in a context where conventional definitions of this term are very few- for the first time a treaty adopts a strongly socially-based 'gender' definition.

${ }^{124}$ Ibid., paragraph Ioo.

${ }^{125}$ Among others, see Case of Christine Goodwin cit., paragraph 90 where the Court mentions "one gender or the other", and paragraph 97, where it refers to "the sex opposite to their re-assigned gender" so once again using gender and sex as (at least to some extent) bi-univocally dependent and in the framework of a binary system. 
Nonetheless, apparently this novelty cannot to be regarded also as a real innovation in International Law concerning 'gender' issues, and the attempt to introduce a pure socially-based 'gender' definition cannot be said to have been fulfilled. It seems to be so by reason of - at leastthree different elements.

First of all, at least at first instance, this socially-based definition is due - once again - to experts and not to the will and to the negotiation of states, even if contained in a treaty. On the contrary, the will of the states has been 'sterilized' by the adoption of the convention without a vote. Moreover, the fact that, in the framework of the Council of Europe, for the very first time a convention has been adopted without a vote (and with strong resistance from states) shows once again how problematic it was to gain consensus on this text.

Notwithstanding this circumstance, and this is the second element that deserves to be emphasized, Governments that took part in the negotiation of this treaty showed an attitude that seems to confirm their tendency to be reluctant to any definition which is unbalanced towards social theories. Indeed, since their attempt to modify the text of the Convention itself had been barred, they introduced deep modifications in Paragraph 43 of the Explanatory Report, which contains the explanation of the definition adopted by Article $3(\mathrm{c})$. In doing so states showed to share a much more balanced position, by properly acknowledging, on one hand, an important role to society in influencing (often in a discriminatory way) gender issues, while strongly reconnecting at the same time gender to sex and in particular to 'two sexes', this way circumscribing the role played by society within the borders of biology, i.e. of two given sexes: male and female. This brings the meaning of 'gender' much more closer to the Rome Statute definition (and the subsequent ones, like the definition contained in Durban I), according to which "the term 'gender' refers to the two sexes, male and female, within the context of society", as recalled above. With such authentic interpretation of the definition contained in Article 3(c), the states unambiguously confirmed their usual approach, by unequivocally reconstructing a close relationship between biological and social elements and clearly moving away from a socially-based construction.

As interpreted in the light of Paragraph 43 of the Explanatory Report, the 'gender' definition contained in Article 3 (c) appears to be fitting with the personalistic perspective of 'gender'. This definition, indeed, is not just 'flattened' on a biological approach, but at the same time is not so biased to deny any relevance to the objective sex of an individual: it recognizes a fundamental role to sex as well as to gender, thought as strongly linked to sex- in the conception of personal identity, also from the juridical point of view.

Thirdly, the fact that this definition - as well as the whole Convention- has been approved without a vote, barring any real debate among states on the basis of the Draft text proposed by experts, makes it very difficult to ascertain the real future intention of those states, who have signed the Convention and now have to ratify it, in a context that leaves very little space for reservation. ${ }^{26}$ Generally speaking, in a context where a convention has to be adopted unanimously and it is not possible to intervene on a draft text in order to modify it - as it happened in this occasion, for the

${ }^{126}$ See Art. 78 of the Convention. 
first time in the history of the Council of Europe-, it is diplomatically safer and more 'politically correct' to vote in favour of it - so not 'vetoing' the adoption - and then not to ratify the treaty.

Defining 'gender' as 'the socially constructed roles, behaviour, activities and attributes that a given society considers appropriate for women and men", in fact, means to follow the less shared of gender theories, ${ }^{\mathrm{I} 27}$ the 'social' one, while recent history of international relations shows how states are very far from agreeing with such a perspective. This approach, while being strongly debated even in recent psychological and medical studies, ${ }^{128}$ has caused from the International Law point of view problems and delays in adopting other important international documents, also in the framework of the Council of Europe. ${ }^{\text {I29 }}$ Moreover, Article $3(\mathrm{c})$ of the Convention and Paragraph 43 of the Explanatory Report build up a compromise that appears to be not very sound and that could be judged as not satisfying by those states called to introduce the provisions of this treaty in their own national systems. ${ }^{\mathrm{I} 0}$

By acting this way, the achievement of a good convention capable of efficiently protecting women rights has been sacrificed in order to protect a particular political interest, with the complicity of some states. ${ }^{\mathrm{I} I}$ Owing to such a despicable hastiness, the surreptitious introduction of this definition in the Convention - that adds nothing to women protection, while pursuing different aims that are highly sensitive from a theoretical and ideological point of view and, above all, not declared - together with other huge juridical problems contained in the treaty, ${ }^{132}$ put its ratification by states in serious danger. Most of these problems could have been solved through negotiation, but the states involved

${ }^{127}$ For a study of the debate relating with these theories see K. Woodward (ed), Identity and Difference (The Open University, Milton Keynes, 1997).

${ }_{12} 8$ Among others, see M. Pale Fritschi, 'Aproximación psicológica: el sexo, el género y sus derivados', in Persona $y$ genero, supra n. 17, at 357-376; and N. López Moratalla, 'Una aproximación científica a la ideología de género: cerebro de mujer, cerebro de varón', in ibid.,at 323-355.

${ }^{22} 2$ For example, see the debate on 'gender' related issues during the adoption of the Declaration on Discrimination on the Basis of Sexual Orientation and Gender Identity (see the Report of the seventeenth sitting of the 2oro Ordinary Session of the PACE, held on 29 April 2010, available <http://www.assembly.coe.int/Main.asp?link=/Documents/Records/2010/E/I004291500E.htm>, accessed 4 September 20I4). On a universal level, in a similar way, serious problems of this kind have risen also during the adoption of the Rome Statute of the International Criminal Court (see Oosterveld supra n. 46, at 62 ff., which states, at 63, that a same point "the debate had come to an impasse on the term 'gender' " and, at 65, that "there was precedent for this level of disagreement") and the Fourth World Conference on Women of Beijing (see what stated above, in the section "The Lack of International Consent on Such a Definition"; see also Adolphe supra n. 66, at 138 ff.).

130 The Italian Government, for example, in signing this Convention added a Declaration according to which "it will apply the Convention in conformity with the principles and the provisions of the Italian Constitution" (see the list of declarations made with respect to the treaty, available <http://conventions.coe.int/Treaty/Commun/ListeDeclarations.asp? $\mathrm{NT}=2 \mathrm{IO} \& \mathrm{CM}=\mathrm{I} \& \mathrm{DF}=23 / \mathrm{II} / 20 \mathrm{I} 2 \& \mathrm{CL}=\mathrm{ENG} \& \mathrm{VL}=\mathrm{I}>$, accessed 4 September 2014), thus implicitly but unequivocally expressing its concern about the danger of unpredictable consequences flowing from a treaty whose text has not been deeply discussed and from a definition of 'gender' having the said characteristics.

${ }^{13 \mathrm{I}}$ Many states, following the decision to adopt the Convention without a vote, declared to be disappointed that consensus had not been reached on the Convention and to be particularly concerned by the refusal to discuss the Draft text produced by the experts group, which strongly diminished the quality of the treaty. The Draft text submitted to the Committee of Ministers contained I9 reservations made by II delegations regarding 17 articles and one entire Chapter of the Convention. This is the only reason why for a number a states a speedy ratification and implementation of the Convention might not be possible.

${ }_{132}$ See supra n. 80. 
preferred to put form (to adopt the Convention quickly and in Istanbul) before substance (to really protect women rights). Such behaviour, nonetheless, puts the broad ratification of the Convention itself in serious danger. Everybody knows, indeed, how 'simple' it is for a state to sign a Convention - particularly human rights conventions - and at the same time how difficult it could be to ratify it, especially when such a treaty contains strong and unclear provision binding states on sensitive issues, perceived as inherent to domestic jurisdiction.

The number of ten ratification needed for the Convention to enter into force, according to Article 75, Paragraph 3 of the Convention itself, has been reached only last April, more than three years having passed since the signing of the treaty, so the Convention has just entered into force ${ }^{\mathrm{I3} 3}$. At this moment, just a small minority of member states of the Council of Europe and none among nonmember states have ratified it. This appears a clear indication of the great difficulties that such an important Convention is facing to be approved at the national level.

Yet we strongly hope that diplomatic opportunism and party-interest will not produce this deleterious consequence of barring the achievement of those commendable goals the Convention aims at (preventing and combating violence against women and domestic violence) and that such partially failed attempt to introduce a new 'gender' definition will not lead to a fully successful —even if undesired- weakening of women's rights.

${ }^{133}$ See supra n. 5. 